\title{
PENGARUH METODE MUSIKALISASI BERCERITA TERHADAP KEMAMPUAN MENGENAL KONSEP BILANGAN ANAK USIA 4-5 TAHUN DI TAMAN KANAK- KANAK
}

\author{
Yusan Maulani ${ }^{1}$ \\ Ai Sutini ${ }^{2}$ \\ Dudung Priatna ${ }^{3}$
}

\begin{abstract}
ABSTRAK
Konsep bilangan merupakan salah satu konsep dalam matematika dan merupakan suatu pondasi bagi anak usia dini untuk memahami konsep matematika pada tahap pendidikan selanjutnya. Tujuan penelitian ini adalah untuk mengetahui peningkatan kemampuan mengenal konsep bilangan anak yang mengikuti pembelajaran metode musikalisasi bercerita. Metode penelitian yang digunakan adalah kuasi eksperimen dengan desain kuasi ekperimen nonequivalent control group design. Pada penelitian ini diambil dua sampel penelitian yaitu kelas A (kelompok eksperimen) dan kelas A (kelas kontrol) di TK Al-Inayah dan TK Permata Bunda. Proses penelitian ini yaitu memberikan pretest terlebih dahulu sebelum diberikan treatment, pretest dilakukan untuk mengetahui kemampuan awal anak sebelum diberikan treatment. Teknik analisis data yang digunakan adalah analisis data kuantitatif dan kualitatif. Hasil analisis data kuantitatif terhadap uji gain ternormalisasi dari kelompok eskperimen dan kelompok kontrol mampu menujukkan peningkatan kemampuan mengenal konsep bilangan anak sebesar 0,78 dan 0,49 dengan interpretasi tinggi dan sedang. Analisis data kualitatif yaitu lembar observasi dengan mendeskripsikan hasil dari data yang didapat. Berdasarkan analisis data hasil penelitian diperoleh kesimpulan: 1) Terdapat peningkatan kemampuan mengenal konsep bilangan dengan menggunakan metode musikalisasi bercerita; 2) Terdapat peningkatan kemampuan mengenal konsep bilangan dengan menggunakan metode konvensional (metode bermain); 3) Peningkatan kemampuan mengenal konsep bilangan anak yang memperoleh pembelajaran menggunakan metode musikalisasi bercerita lebih baik daripada anak yang memperoleh metode konvensional (metode bermain).
\end{abstract}

Kata Kunci : konsep bilangan, musikalisasi bercerita.

\footnotetext{
${ }^{1}$ yusanmaulani12345@gmail.com

2 Dosen Kampus UPI Cibiru

${ }^{3}$ Dosen Kampus UPI Cibiru
} 


\section{A. PEMDAHULUAN}

Pedidikan adalah proses pertumbuhan dan perkembangan potensi pada diri individu, jika tidak diiringi dengan proses belajar maka pontensi-potensi yang ada pada diri individu tidak akan tumbuh dan berkembang secara optimal. Dalam UU No 20 Tahun 2003 tentang pendidikan, disebutkan bahwa tujuan pendidikan nasional adalah membentuk manusia Pancasila, yang mempunyai tujuan institusional yaitu etika (moral), estetika (emosi), logika (penalaran), dan praktik (Faidi, 2013). Proses belajar lahir dari proses berpikir dan aktualisasi hasil pemikiran dalam kehidupan nyata, maka dengan adanya proses belajar tersebut diharapkan dapat mencapai pada tujuan pendidikan dan dapat meningkatkan mutu pendidikan.

Pendidikan harus dipersiapkan pada anak usia dini, karena Pendidikan Anak Usia Dini (PAUD) merupakan pendidikan yang bertujuan untuk memfasilitasi pertumbuhan dan perkembangan anak secara menyeluruh. Menurut Mulyasa (2012, hlm.25) PAUD memegang peranan yang sangat penting dan menentukan bagi sejarah perkembangan anak selanjutnya karena merupakan fondasi bagi dasar kepribadian anak.

Bentuk PAUD formal yaitu Taman Kanak-Kanak (TK). TK adalah salah satu bentuk satuan PAUD pada jalur formal yang menyelenggarakan program pendidikan bagi anak usia 4-6 tahun atau masa pra-sekolah. Jenjang pendidikan formal (Taman Kanak-Kanak) terbagi menjadi 2 kelompok yang disesuaikan dengan usia, anak dengan usia 4-5 tahun dikelompokkan ke dalam kelompok A, sedangkan anak usia 5-6 tahun dikelompokkan ke dalam kelompok B.

Anak dengan rentang usia 0-6 tahun atau yang dapat dikatakan sebagai anak usia dini merupakan individu yang sedang mengalami proses pertumbuhan dan perkembangan yang sangat pesat. Kegiatan yang di dapat pada masa ini akan tersimpan dalam jangka waktu lama dan akan mempengaruhi pada kehidupan yang akan datang. Oleh karena itu stimulus yang diberikan sejak anak usia dini harus benar-benar diperhatikan secara khusus karena kunci dari tercapainya tahapan pertumbuhan dan perkembangan yaitu stimulus yang didapatkan oleh anak baik itu yang didapat di lingkungan formal maupun di lingkungan informal.

PAUD khususnya TK perlu menyiapkan stimulus-stimulus dan kegiatankegiatan yang dapat mengembangkan berbagai aspek perkembangan anak yang meliputi aspek perkembangan kognitif, perkembangan fisik-motorik, perkembangan sosial-emosional, perkembangan moral-agama, perkembangan bahasa, dan seni. Salah satu contoh aspek perkembangan yang sangat perlu dikembangkan pada anak usia dini adalah aspek perkembangan kognitif.

Kognitif sering disinonimkan dengan intelektual karena prosesnya sering dihubungkan dengan berbagai konsep yang telah dimiliki anak dan berkenaan dengan kemampuan berfikirnya dalam memecahkan suatu masalah. Faktor kognitif mempunyai peranan penting bagi keberhasilan anak dalam belajar, sebagian aktivitas belajar selalu berhubungan dengan mengingat dan berfikir (Mulyasa, 
2012). Sehingga kognitif merupakan suatu proses berfikir yang berhubungan dengan tingkat kecerdasan seseorang dan perkembangan otak anak akan tumbuh terus menerus sejak lahir. Pengembangan kognitif bertujuan agar anak mampu melakukan eksplorasi terhadap dunia sekitar melalui panca inderanya yang nantinya akan anak eksplorasi di lingkungan sekitarnya

Kegiatan pada kemampuan kognitif merupakan hal yang sangat penting, dimana bertujuan untuk mengembangkan kemampuan berfikir anak, dapat memecahkan suatu permasalahan, mempersiapkan kemampuan berfikir teliti, dan kemampuan logika matematikanya. Salah satu kemampuan logika matematika yang dihubungkan dengan perkembangan kognitif anak yaitu mengenal konsep bilangan. Oleh karena itu, kemampuan matematika dasar perlu dikenalkan dan dikembangkan sejak dini agar dapat berkembang secara optimal dan menyeluruh (Sriningsih, 2009).

Salah satu kegiatan matematika dasar yang harus dikenalkan kepada anak yaitu mengenal konsep bilangan, dimana bilangan pada matematika bersifat abstrak sehingga undefine (tidak dapat didefinisikan). Mengenal konsep bilangan merupakan dasar kegiatan matematika anak untuk kegiatan selanjutnya. Dalam kehidupan, pada dasarnya tidak akan terlepas dari yang namanya bilangan, anakanak akan menemukan bilangan dimanapun ia berada seperti contoh pada plat nomor kendaraan orang tuanya, nomor rumah, dalam berbagai permainan, pada saat bermain, dll. Sehingga menjadi penting mengenal dan mempelajari matematika khususnya konsep bilangan sejak usia dini secara detail dan mendasar. Untuk berhasil di sekolah dan dalam kehidupan anak-anak muda perlu fondasi yang kuat dalam matematika. Matematika membantu anak-anak memahami dunia mereka di luar sekolah dan membantu mereka membangun dasar yang kokoh untuk keberhasilan di sekolah, tidak hanya di kursus matematika tetapi juga dalam ilmu pengetahuan, ilmu sosial, dan mata pelajaran lain. (NAEYC dan NCTM dalam Marcelino dkk, 2012). Semua orang yang memahami dan dapat menggunakan matematika, akan memiliki lebih banyak kesempatan dan pilihan untuk menentukan masa depan mereka (Coronata \& Alsina, 2014).

Idealnya bahwa mengenalkan matematika kepada anak terdapat 3 tahapan penting yaitu belajar dengan menggunakan benda konkret/nyata, belajar membuat bayangan di pikiran, dan yang terakhir menggunakan simbol/lambang. jelas terlihat bahwa lambang/simbol dalam matematika menjadi penting untuk dikenalkan karena merupakan bagian utama sebelum anak mengenal konsep matematika lebih dalam (Setyono, 2005). Setyono (2005, hlm.45) juga berpendapat bahwa dasar penguasaan konsep matematika harus kuat sejak usia dini. Setiap proses harus dilalui dengan baik sehingga pemahaman anak cukup mendalam dan mantap, hapalan saja tidak mencukupi jika kita ingin membentuk konsep dasar yang kuat.

Namun kenyataan di lapangan berdasarkan hasil pengamatan dan wawancara, masih banyak anak yang hanya mengenal konsep bilangan dengan stimulus yang kurang tepat, anak diperkenalkan lambang bilangan dengan teknik yang kurang tepat sehingga anak hanya akan menghafal urutan bilangan tersebut 
tanpa mengenal secara jelas lambangnya, belum paham betul urutan yang benar, belum mengenal konsep-konsep matematika sederhana lainnya namun anak sudah dituntut untuk mengetahui lebih dalam mengenali konsep matematika yang lebih kompleks seperti berhitung. Masih banyak pula anak usia dini yang kesulitan dalam mengenal konsep bilangan, itu dikarenakan penyampaian kegiatan yang terlalu menekankan pada anak untuk bisa dan paham, sehingga membuat anak merasa terbebani dan bosan. Tidak hanya itu, tidak adanya variasi/penyampaian yang menarik dalam pembelajarannya bisa menjadi faktor kurang tepatnya stimulus yang didapatkan oleh anak, dan kurang maksimal tersampainya tujuan pembelajaran.

Berdasarkan kenyataan di atas, maka diperlukan suatu metode kegiatan yang menyenangkan untuk anak, mudah dipahami anak, serta anak akan cepat memahami kegiatan yang disampaikan khususnya dalam mengenal konsep bilangan. Metode kegiatan merupakan teknik atau cara agar tujuan kegiatan tercapai (Hariwijaya \& Sukaca, 2007). Kegiatan pengenalan bilangan harus dikemas dengan menarik agar tujuan yang diharapkan dapat tersampaikan. Menurut Kersh \& Young (2004, hlm. 168) bahwa konsep matematika efektif diajarkan kepada anak-anak melalui media kisah-kisah cerita lisan. Sehingga Storytelling menjadi efektif dalam mengenalkan matematika kepada anak usia dini. Memodifikasi metode bercerita akan lebih menarik, yaitu dengan metode musikalisasi bercerita. Musikalisasi bercerita adalah bercerita dengan iringan musik dan pemberian nada dalam setiap kalimat cerita yang akan disampaikan sesuai dengan suasana isi cerita. Dalam cerita yang disampaikan oleh guru terdapat pengenalan angka yang dikemas secara menarik oleh guru agar dapat tersampaikan tujuan yang diinginkan yaitu mengenalkan konsep bilangan pada anak. Menurut Idris (2014, hlm. 183) anak dengan rentan usia 3-6 tahun sudah dapat pula diperkenalkan cerita yang mengandung unsur gambar huruf dan angka yang berkaitan dengan kehidupan sehari-hari sehingga menjadi tepat apabila mengenalkan konsep bilangan melalui cerita.

Berdasarkan permasalahan yang telah dipaparkan di atas, pengenalan konsep bilangan pada anak usia dini disampaikan dengan menggunakan metode musikalisasi bercerita. Musikalisasi bercerita dianggap menjadi metode yang tepat untuk membangkitkan minat anak dalam mendengarkan cerita yang disampaikan dan membangkitkan konsentrasi anak dalam menangkap makna yang akan disampaikan oleh guru dalam bercerita tersebut sehingga mampu meningkatkan kemampuan mengenal konsep bilangan pada anak. Maka dari itu mengenai Pengaruh Metode Musikalisasi Bercerita Terhadap Kemampuan Mengenal Konsep Bilangan pada Anak Usia 4-5 Tahun di Taman Kanak-Kanak dianggap perlu untuk dilakukan. Penelitian ini diharapkan dapat menjadi salah satu solusi dalam mengenalkan konsep bilangan pada anak usia dini

\section{B. METODE}

Penelitian ini menggunakan desain kuasi ekperimen the matching only pretest-posttest control group design. Penelitian kuasi eksperimen ini terdiri dari 
dua kelompok yaitu kelompok eksperimen dan kelompok kontrol, untuk membandingkan kemampuan mengenal konsep bilangan anak usia 4-5 tahun antar kelompok eksperimen yang menggunakan treatment (perlakuan) dengan menggunakan metode musikalisasi bercerita dengan kelompok kontrol yang diberikan treatment (perlakuan) dengan menggunakan metode bermain permainan. Perlakuan diberikan setelah masing-masing kelompok melaksanakan kegiatan observasi awal (pretesttt). Selanjutnya, kelompok eksperimen diberikan perlakuan menggunakan metode Musikalisasi bercerita, sedangkan pada kelompok kontrol dengan menggunakan metode bermain permainan. Setelah diberikan perlakuan selama 4 kali Kegiatan maka masing-masing sampel melaksanakan kegiatan observasi akhir/Posttestt (Ruseffendi, 2010; Sugiyono, 2014)

Penelitian dilaksanakan TK Al-Inayah dan TK Permata Bunda Kecamatan Cileunyi Kabupaten Bandung. Sampel dalam penelitian dipilih 1 kelompok dari setiap TK. Satu kelompok sebagai kelompok eksperimen dan kelompok lainnya sebagai kelompok kontrol.

Instrumen yang digunakan dalam penelitian ini yaitu berupa soal tes yang mengukur kemampuan mengenal konsep bilangan dalam bentuk pilihan gambar yang nantinya akan memasangkan/menghubungan gambar, dengan bantuan lembar penilaian performa yang akan diisi oleh guru guna menilai hasil tes tiap anak. Instrumen lain yang digunakan dalam penelitian ini adalah lembar observasi yang ditujukan untuk menunjang kelengkapan data kegiatan pembelajaran yang telah dilakukan.

Teknis analisis data kuantitatif dilakukan dengan menggunakan uji statistika parametrik atau non parametrik. Data kuantitatif di dapat dari data pretest, posttest dan gain ternormalisasi kelompok eksperimen dan kelompok kontrol. Data pretest dan gain ternormalisasi kelompok eksperimen dan kelompok kontrol selanjutnya diolah dan dianalisis dengan melakukan uji normalitas, uji homogenitas dan uji perbedaan rerata. Apabila populasi berasal dari sampel yang berdistribusi normal dan homogen berdasarkan hasil uji normalitas dan uji homogenitas, maka pengujian dilanjutkan pada uji statistika parametrik yaitu uji t. Apabila populasi berasal dari sampel yang tidak berdistribusi normal berdasarkan hasil uji normalitas, maka pengujian selanjutnya dilakukan uji statistika non-parametrik yaitu uji Mann-Whitney.

Data pretest diolah dan dianalisis untuk mengetahui ada tidaknya perbedaan kemampuan mengenal konsep bilangan sebelum anak memperoleh perlakuan pada kedua kelompok. Data gain ternormalisasi diolah dan dianalisis untuk mengetahui ada tidaknya peningkatan kemampuan mengenal konsep bilangan kelompok eksperimen, untuk mengetahui ada tidaknya peningkatan kemampuan mengenal konsep bilangan kelompok kontrol, dan untuk mengetahui apakah terdapat perbedaan peningkatan kemampuan mengenal konsep bilangan anak yang diberi perlakuan metode musikalisasi bercerita dengan anak yang diberi perlakuan pembelajaran konvensional (metode bermain). 
Analisis data kualitatif yaitu lembar observasi, dilakukan dengan mendeskripsikan hasil dari data yang didapat. Deskripsi dilakukan untuk memudahkan dalam pembahasan.

\section{PEMBAHASAN}

1. Deskripsi Data Hasil Penelitian

Penelitian diawali dengan pemberian pretest pada kelompok eksperimen dan kelompok kontrol. Pemberian pretest bertujuan untuk mengukur kemampuan mengenal konsep bilangan anak sebelum mendapat perlakuan di masing-masing kelompok.

Tahap berikutnya masing-masing kelompok mendapatkan empat kali perlakuan/treatment. Pada kelompok eksperimen, pembelajaran dilakukan menggunakan metode musikalisasi bercerita, sedangkan kelompok kontrol mendapatkan pembelajaran konvensional yaitu metode bermain. Selanjutnya, masing-masing kelompok diberikan posttest dengan tujuan untuk mengetahui kemampuan mengenal konsep bilangan setelah mendapat perlakuan.

Hasil analisis data pretest dan posttest dapat dilihat pada tabel berikut. Tabel 1.1

\begin{tabular}{cccccc}
\multicolumn{5}{c}{$\begin{array}{c}\text { Rekapitulasi Nilai Statistik Kemampuan Mengenal Konsep Bilangan } \\
\text { Kelompok Eksperimen dan Kelompok Kontrol } \\
\text { Descriptive Statistics }\end{array}$} \\
\hline \multicolumn{1}{c}{ N } & Min & Max & Mean & $\begin{array}{c}\text { Std. } \\
\text { Dev }\end{array}$ \\
\hline $\begin{array}{c}\text { Pretest } \\
\text { Eksperimen }\end{array}$ & $\mathbf{1 5}$ & $\mathbf{8 , 0 0}$ & $\mathbf{1 3 , 0 0}$ & $\mathbf{9 , 9 3}$ & $\mathbf{1 , 3 3}$ \\
\hline $\begin{array}{c}\text { Pretest } \\
\text { Kontrol }\end{array}$ & $\mathbf{1 5}$ & $\mathbf{6 , 0 0}$ & $\mathbf{1 2 , 0 0}$ & $\mathbf{9 , 6 0}$ & $\mathbf{1 , 5 9}$ \\
\hline $\begin{array}{c}\text { Posttest } \\
\text { Eksperimen }\end{array}$ & $\mathbf{1 5}$ & $\mathbf{1 3 , 0 0}$ & $\mathbf{1 6 , 0 0}$ & $\mathbf{1 4 , 6 0}$ & $\mathbf{0 , 9 8}$ \\
\hline $\begin{array}{c}\text { Posttest } \\
\text { Kontrol }\end{array}$ & $\mathbf{1 5}$ & $\mathbf{1 0 , 0 0}$ & $\mathbf{1 6 , 0 0}$ & $\mathbf{1 2 , 6 0}$ & $\mathbf{1 , 7 2}$ \\
\hline
\end{tabular}

Selain hasil analisis data pretest dan posttest kelompok eksperimen dan kelompok kontrol, hasil gain ternormalisasi kedua kelompok pun didapatkan dengan rumus seperti yang dirumuskan oleh Frank Gery (dalam Bao, 2006) dan menurut Lestari \& Yudhanegara (2015, hlm. 234-236):

Gain ternormalisasi $(\mathrm{g})=\frac{\text { skor postes }- \text { skor pretes }}{\text { skor ideal }- \text { skor pretes }}$

Hasil gain ternormalisasi ditujukan untuk mengetahui peningkatan kemampuan mengenal konsep bilangan ana $\mathrm{k}$ pada kelompok eksperimen dan kelompok kontrol. Hasil analisis data gain ternormalisasi dapat dilihat pada tabel berikut. 
Tabel 1.2

Rekapitulasi Nilai Statistik Kemampuan Berpikir Kritis Kelompok Eksperimen dan Kelompok Kontrol Descriptive Statistics

\begin{tabular}{cccccc}
\hline & $\mathbf{N}$ & Min & Max & Mean & $\begin{array}{c}\text { Std. } \\
\text { Dev }\end{array}$ \\
\hline $\begin{array}{c}\text { Gain } \\
\text { ternormalisasi } \\
\text { Eksperimen }\end{array}$ & $\mathbf{1 5}$ & $\mathbf{0 , 6 0}$ & $\mathbf{1 , 0 0}$ & $\mathbf{0 , 7 8}$ & $\mathbf{0 , 1 4}$ \\
\hline $\begin{array}{c}\text { Gain } \\
\text { ternormalisasi } \\
\text { Kontrol }\end{array}$ & $\mathbf{1 5}$ & $\mathbf{0 , 2 5}$ & $\mathbf{1 , 0 0}$ & $\mathbf{0 , 4 9}$ & $\mathbf{0 , 2 1}$ \\
\hline
\end{tabular}

2. Analisis Data Penelitian

a. Pengujian Prasyarat Analisis

Pengujian prasyarat analisis dilakukan sebelum data pretest dan gain ternormalisasi di uji hipotesis melalui uji perbedaan rerata. Data pretest dan gain ternormalisasi yang telah terkumpul terlebih dahulu harus di uji normalitas dan homogenitasnya. Uji normalitas ditujukan untuk mengetahui sampel berasal dari populasi yang berdistribusi normal atau tidak, sedangkan uji homogenitas ditujukan untuk mengetahui apakah sampel berasal dari populasi yang sama variansnya atau tidak.

Uji normalitas yang dilakukan adalah uji statistik Kolmogorov-Smirnov untuk data $\leq 30$. Berdasarkan data hasil uji normalitas pretest kelompok eksperimen, didapatkan nilai signifikansi yaitu 0,200. Pretest kelompok kontrol mendapatkan nilai signifikansi yaitu 0,113 . Nilai signifikansi pretest kelompok eksperimen dan pretest kelompok kontrol, menunjukkan data pretest kedua kelompok berasal dari populasi yang berdistribusi normal karena nilai signifikansi $\geq 0,05$.

Hasil uji normalitas gain ternormalisasi kelompok eksperimen mendapatkan nilai signifikansi yaitu 0,200. Gain ternormalisasi kelompok kontrol mendapatkan nilai signifikansi yaitu 0,121. Nilai signifikansi gain ternormalisasi kelompok eksperimen dan kelompok kontrol, menunjukkan data gain ternormalisasi kedua kelompok berasal dari populasi yang berdistribusi normal karena nilai siginifikasi $\geq 0,05$.

Selanjutnya setelah distribusi data pretest dan gain ternormalisasi kelompok eksperimen dan kontrol diketahui melalui uji normalitas, uji prasyarat ke dua setelah uji normalitas yaitu uji homogenitas. Uji homogenitas dilakukan dengan uji F Homogen of Varians (Levene Statistic).

Uji homogenitas pretest kelompok eksperimen dan kelompok kontrol diperoleh nilai signifikansi yaitu 0,401 . Uji homogenitas gain ternormalisasi kelompok eksperimen dan kelompok kontrol diperoleh nilai signifikansi yaitu 0,282 . Hasil tersebut menunjukkan data pretest dan gain ternormalisasi tidak 
terdapat perbedaan varians antara kedua kelompok sampel karena nilai signifikansi $\geq 0,05$.

b. Pengujian Hipotesis

Uji perbedaan rerata ditujukan untuk menguji hipotesis. Uji perbedaan rerata yang digunakan adalah uji t dengan asumsi data berasal dari populasi yang berdistribusi normal dan homogen.

Uji hipotesis pertama dilakukan untuk membuktikan bahwa kemampuan awal anak mengenai kemampuan mengenal konsep antara kelompok eksperimen dan kelompok kontrol itu setara. Uji hipotesis ini dilakukan dengan menggunakan uji t dua sampel (independent sample t-test). Data yang digunakan adalah data pretest kelompok eksperimen dan data pretest kelompok kontrol.

Berdasarkan perhitungan uji perbedaan rerata dengan uji t dua sampel (independent sample t-test) diperoleh nilai signifikansi perbedaan rerata pretest antara kelompok eksperimen dan kelompok kontrol yaitu 0,540. Hasil tersebut menunjukkan bahwa $0,540 \geq 0,05$ sehingga $\mathrm{H}_{0}$ diterima. Artinya tidak terdapat perbedaan kemampuan mengenal konsep bilangan antara kelompok eksperimen dan kelompok kontrol. Dengan kata lain, kemampuan awal anak dapat diasumsikan setara.

Uji hipotesis kedua dilakukan untuk membuktikan bahwa terdapat peningkatan kemampuan mengenal konsep bilangan anak pada kelompok eksperimen. Uji hipotesis ini dilakukan dengan menggunakan data gain ternormalisasi uji t satu sampel (One Sample T-Test). Data yang digunakan adalah data gain ternormalisasi kelompok eksperimen.

Berdasarkan perhitungan uji perbedaan rerata dengan uji t satu sampel (one sample t-test) diperoleh nilai signifikansi perbedaan rerata gain ternormalisasi kelompok eksperimen yaitu 0,000 . Hasil tersebut menunjukkan bahwa $0,000<0,05$ sehingga $\mathrm{H}_{0}$ ditolak. Artinya terdapat peningkatan kemampuan mengenal konsep bilangan anak menggunakan metode musikalisasi bercerita.

Uji hipotesis ketiga dilakukan untuk membuktikan bahwa terdapat peningkatan kemampuan mengenal konsep bilangan anak pada kelompok kontrol. Uji hipotesis ini dilakukan dengan menggunakan data gain ternormalisasi uji t satu sampel (One Sample T-Test). Data yang digunakan adalah data gain ternormalisasi kelompok kontrol.

Berdasarkan perhitungan uji perbedaan rerata dengan uji t satu sampel (one sample t-test) diperoleh nilai signifikansi perbedaan rerata gain ternormalisasi kelompok kontrol yaitu 0,000. Hasil tersebut menunjukkan bahwa $0,000<0,05$ sehingga $\mathrm{H}_{0}$ ditolak. Artinya terdapat peningkatan kemampuan mengenal konsep bilangan anak menggunakan pembelajaran konvensional yaitu metode bermain.

Uji hipotesis keempat dilakukan untuk membuktikan bahwa terdapat perbedaan peningkatan kemampuan mengenal konsep bilangan anak yang memperoleh pembelajaran menggunakan metode musikalisasi bercerita dengan anak yang memperoleh pembelajaran konvensional (metode bermain). Uji hipotesis ini dilakukan dengan menggunakan uji t dua sampel (independent 
sample t-test). Data yang digunakan adalah data gain ternormalisasi kelompok eksperimen dan data gain ternormalisasi kelompok kontrol.

Berdasarkan perhitungan uji perbedaan rerata gain ternormalisasi dengan uji t dua sampel (independent sample t-test) diperoleh nilai signifikansi perbedaan rerata gain ternormalisasi antara kelompok eksperimen dan kelompok kontrol yaitu 0,000. Hasil tersebut menunjukan bahwa 0,000 $<0,05$ sehingga $\mathrm{H}_{\mathrm{a}}$ diterima. Artinya terdapat perbedaan peningkatan kemampuan mengenal konsep bilangan pada anak usia 4-5 tahun antara yang memperoleh metode pembelajaran musikalisasi bercerita dan yang memperoleh pembelajaran konvensional (metode bermain).

\section{Pembahasan}

Peningkatan kemampuan mengenal konsep dapat dilihat dari terdapat kenaikan rata-rata kemampuan mengenal konsep bilangan di kelompok eksperimen yaitu pada saat pretest sebesar 9,93 menjadi 14,6 pada saat posttest, selanjutnya terdapat kenaikan rata-rata kemampuan mengenal konsep bilangan kelompok kontrol yaitu pada saat pretest sebesar 9,85 menjadi 12,5 pada saat posttest. Lebih lanjut, peningkatan kemampuan mengenal konsep bilangan anak dapat dilihat dari hasil rata-rata uji gain ternormalisasi, didapatkan hasil perhitungan pada kelompok eksperimen sebesar 0,78 dengan interpretasi tinggi, sedangkan pada kelompok kontrol peningkatan kemampuan mengenal konsep bilangan anak sebesar 0,49 dengan interpretasi sedang.

Peningkatan kemampuan mengenal konsep bilangan anak secara signifikan dibuktikan melalui uji perbedaan rerata satu sampel yang menunjukkan terdapat peningkatan kemampuan mengenal konsep bilangan anak pada kelompok eksperimen dan kelompok kontrol. Selain itu, uji perbedaan rerata juga menunjukkan terdapat perbedaan peningkatan kemampuan mengenal konsep bilangan pada anak usia 4-5 tahun antara yang memperoleh metode pembelajaran musikalisasi bercerita dengan yang memperoleh pembelajaran konvensional (metode bermain).

Analisis lembar observasi secara keseluruhan menunjukkan bahwa Pada pertemuan pertama sampai pertemuan keempat kemunculan setiap aktivitas guru dan anak selalu muncul (Ya). Dari hasil penilaian observer, secara keseluruhan aktivitas guru sudah dilakukan dengan baik serta mengalami peningkatan pada setiap pertemuannya. Tak jauh berbeda dengan aktivitas guru, aktivitas anak dalam pembelajaran metode musikalisasi bercerita juga sudah baik. Terlihat dengan peningkatan yang terjadi setiap pertemuannya, baik dari pertemuan pertama sampai keempat. Dengan demikian, maka dapat disimpulkan bahwa aktivitas guru dan anak dalam empat kali pembelajaran telah berlangsung dengan baik.

\section{KESIMPULAN}

Berdasarkan hasil penelitian dan pembahasan, peneliti memberikan kesimpulan sebagai berikut: 
1. Kemampuan mengenal konsep bilangan dengan menggunakan metode musikalisasi bercerita mengalami peningkatan sebesar 0,78 dengan interpretasi tinggi berdasarkan hasil uji gain ternormalisasi. Kegiatan pembelajaran dengan menggunakan metode musikalisasi bercerita mampu mendorong anak untuk meningkatkan kemampuan mengenal konsep bilangan dengan baik. Pernyataan tersebut, diperkuat oleh hasil uji perbedaan rerata satu sampel yang menunjukkan nilai signifikansi kurang dari 0,05 yaitu 0,000. Dengan demikian dapat disimpulkan bahwa "terdapat peningkatan kemampuan mengenal konsep bilangan dengan menggunakan metode musikalisasi bercerita".

2. Kemampuan mengenal konsep bilangan dengan menggunakan metode bermain mengalami peningkatan sebesar 0,49 dengan interpretasi sedang berdasarkan hasil uji gain ternormalisasi. Pembelajaran dengan menggunakan metode bermain mampu memunculkan dan meningkatkan kemampuan mengenal konsep bilangan anak dengan cukup baik. Pernyataan tersebut, diperkuat oleh hasil uji perbedaan rerata satu sampel yang menunjukkan nilai signifikansi kurang dari 0,05 yaitu 0,000. Dengan demikian dapat disimpulkan bahwa "terdapat peningkatan kemampuan mengenal konsep bilangan dengan menggunakan metode bermain".

3. Kemampuan mengenal konsep bilangan anak yang memperoleh pembelajaran menggunakan metode musikalisasi bercerita mengalami peningkatan lebih tinggi dibandingkan kemampuan mengenal konsep bilangan anak yang memperoleh metode bermain. Hal tersebut dibuktikan berdasarkan hasil gain ternormalisasi metode musikalisasi bercerita lebih tinggi daripada hasil gain ternormalisasi metode bermain, yaitu 0,78 dan 0,49. Pernyataan tersebut, diperkuat oleh hasil uji perbedaan rerata dua sampel satu pihak yang menunjukkan nilai signifikansi kurang dari 0,05 yaitu 0,000. Dengan demikian dapat disimpulkan bahwa "terdapat perbedaan peningkatan kemampuan mengenal konsep bilangan anak yang memperoleh pembelajaran menggunakan metode musikalisasi bercerita dibandingkan dengan anak yang memperoleh pembelajaran dengan metode musikalisasi bercerita".

\section{REFERENSI}

Bao, L. (2006). Theoretical comparisons of average normalized gain calculations. [Jurnal Online]. Tersedia di : http://www.physics.ohiostate.edu/ lbao/Papers/AJP_2006-10-917-g-factor1.pdf. Diakses 20 Mei 2017.

Coronata, C., \& Alsina, A. (2014). Evaluation of the mathematical processes in the practices of teaching and learning in childhood education. WLCTA 2013, 141, hlm. 1320-1323.

Faidi, A. (2013). Tutorial mengajar untuk melejitkan otak kanan dan otak kiri. Jogjakarta: DIVA Press. 
Hariwijaya, M., \& Sukaca B.E. (2007). PAUD Melejitkan potensi anak dengan pendidikan sejak dini. Bandung: Rizki Press.

Idris, M.H. (2014). Meningkatkan kecerdasan anak melalui dongeng. Jakarta Timur: PT Luxima Metro Media.

Kersh, J.E. \& Young, J.M. (2004). Storytelling Sagas: an Effective medium for teaching early childhood mathematics. Early Childhood Research Quarterly, XIX, hlm. 167-172.

Lestari, K. E. Yudhanegara, M. R. (2015). Penelitian pendidikan matematika. Bandung: Refika Aditama

Marcelino, L., Sausa, D., Cruz, V., Lopes, A. (2012). Multi year longitudinal investigation of children's early mathematics development. International Conference On Education and Educational Psychology (ICEEPSY 2012), 69, hlm. 1911-1920.

Mulyasa, H.E. (2012). Manajemen PAUD. Bandung: PT. Remaja Rosdakarya.

Ruseffendi (2010). Dasar-dasar penelitian pendidikan dan bidang non-eksakta lainnya. Bandung: Tarsito.

Setyono, A. (2005). Mathemagics cara jenius belajar matematika. Jakarta : Grameadia Pustaka Utama.

Sugiyono (2014). Metode penelitian pendidikan. Bandung: Alfabeta.

Sriningsih, N. (2009). Pembelajaran matematika terpadu untuk anak Usia dini. Bandung: Pustaka Sebelas. 